\title{
THE NON-PROTEIN NITROGEN OF THE BLOOD IN HEALTH AND IN HEPATIC DISEASE
}

BY

\author{
MARGARET T. TINDAL, M.B., Ch.B., F.R.F.P.S.*
}

(From the Department of Pædiatrics, Glasgow University, and the Biochemical Laboratory, Royal Hospital for Sick Children, Glasgow.)

It is universally accepted that urea is formed in the liver, and there is a considerable amount of evidence that some is retained there, either unchanged or in an altered form. It is possible that this power of retention prevents the blood becoming flooded with urea after a meal rich in protein, much as the glycogenic function of the liver acts as a barrier to hyperglycæmia. If this is the case, the normal liver should prevent an undue rise in non-protein nitrogen after the ingestion of urea, while the diseased liver should permit the non-protein nitrogen of the blood to rise to an abnormally high level, and to remain elevated for an abnormally long period.

It was shown by Cohen and Levin ${ }^{1}$ that the non-protein nitrogen of the blood rose only after a meal containing nitrogen. The accompanying table (Table 1) shows the results which I have obtained after (a) giving glucose,

TABLE 1.

The INFLUeNCE OF THE INGESTION OF GLUCOSE SOLUTION AND WATER ON THE NON-PROTEIN NITROGEN CURVE.

\begin{tabular}{|c|c|c|c|c|c|c|c|c|}
\hline \multirow{3}{*}{$\begin{array}{l}\text { No. of } \\
\text { case }\end{array}$} & \multirow{3}{*}{$\begin{array}{l}\text { Age in } \\
\text { years }\end{array}$} & \multirow{3}{*}{ Disease } & \multirow{3}{*}{$\begin{array}{l}\text { Substance } \\
\text { given }\end{array}$} & \multicolumn{5}{|c|}{ Percentage N.P.N. in blood : mgrm. per cent. } \\
\hline & & & & \multirow{2}{*}{$\begin{array}{l}\text { Fasting } \\
\text { level }\end{array}$} & \multicolumn{4}{|c|}{$\begin{array}{c}\text { Hours after ingestion of glucose } \\
\text { or water }\end{array}$} \\
\hline & & & & & $\frac{1}{2} \mathrm{hr}$. & $1 \mathrm{hr}$. & $1 \frac{1}{2} \mathrm{hr}$. & $2 \mathrm{hr}$. \\
\hline 1 & 10 & Valvular dis. & Glucose & $44 \cdot 0$ & $37 \cdot 9$ & $30 \cdot 8$ & $30 \cdot 0$ & $23 \cdot 1$ \\
\hline 1 & 10 & , , , & $\begin{array}{l}150 \text { c.cm. } \\
\text { water }\end{array}$ & $40 \cdot 9$ & $25 \cdot 6$ & $\mathbf{2 3} \cdot \mathbf{1}$ & $25 \cdot 0$ & - \\
\hline 2 & 10 & Pulm. fibrosis & Glucose & $\mathbf{3 3 \cdot 3}$ & $\mathbf{3 3} \cdot \mathbf{3}$ & $28 \cdot 0$ & $28 \cdot 0$ & - \\
\hline 2 & 10 & , , , & $\begin{array}{l}150 \text { c.cm. } \\
\text { water }\end{array}$ & $46 \cdot 7$ & $48 \cdot 0$ & $\mathbf{3 0 \cdot 0}$ & $37 \cdot 6$ & $40 \cdot 0$ \\
\hline $\mathbf{3}$ & 11 & Conv. chorea & Glucose & $44 \cdot 6$ & $32 \cdot 4$ & $\mathbf{3 0} \cdot \mathbf{0}$ & $25 \cdot 0$ & $20 \cdot 0$ \\
\hline $\mathbf{3}$ & 11 &,, & $\mathrm{Nil}$ given & $30 \cdot 6$ & $31 \cdot 8$ & $21 \cdot 0$ & - & $\mathbf{3 0} \cdot \mathbf{2}$ \\
\hline 4 & 10 & Renal calculi. & Glucose & $35 \cdot 2$ & $27 \cdot 3$ & $29 \cdot 2$ & $34 \cdot 0$ & $25 \cdot 5$ \\
\hline 4 & 10 &,$\quad$, & Nil given & $29 \cdot 2$ & $28 \cdot 4$ & $27 \cdot 7$ & $20 \cdot 0$ & $18 \cdot 8$ \\
\hline 5 & 7 & Conv. chorea & Glucose & $51 \cdot 0$ & $\mathbf{3 7} \cdot \mathbf{0}$ & $35 \cdot 0$ & $33 \cdot 7$ & $37 \cdot 0$ \\
\hline 5 & 7 & ,, , , & Nil given & $39 \cdot 0$ & $39 \cdot 3$ & $36 \cdot 7$ & $47 \cdot 1$ & $35 \cdot 0$ \\
\hline
\end{tabular}

* This work was done during the tenure of a Muirhead Scholarship. 
(b) giving water only, and (c) a continued fast. From a glance at the figures it is evident that a fall in the fasting level of the non-protein nitrogen took place after the administration of glucose solution, the most marked being in Case 3 where the level fell by almost 25 mgrm. At first it was thought that the glucose was responsible for the fall. When, however, the experiment was repeated on two of the children, but instead of glucose solution the same volume of water alone was given, a similar fall resulted. It now seemed as though it were the water itself which was the cause of the diminution in the non-protein nitrogen. A third experiment was tried on three of the children, to whom neither glucose nor water was given and again a similar fall in the non-protein nitrogen occurred. From this experiment it seems clear that the non-protein nitrogen was not influenced by the taking of either carbohydrate or water, and that the fall observed was due to the continued nitrogen starvation.

The ordinary non-protein nitrogen curve after the ingestion of urea does not seem to have been extensively investigated. Archer and Robb ${ }^{2}$ studied the blood-urea curve in four healthy subjects after the ingestion of $15 \mathrm{grm}$. urea, and they concluded that it usually reached its maximum within half an hour and returned to the fasting level within two hours after the urea had been given. It seems hardly justifiable to base a standard of normality on so small a number of cases, especially as in one instance the blood urea was still considerably above the fasting level at the end of the 2-hour period.

Methods of investigation.-The first specimen of blood was taken at 9 a.m. when the patient had been fasting for at least 12 hours. In one or two instances the blood was taken from a vein, but in the majority it was taken from a needle puncture of the thumb. Johnstone ${ }^{4}$ found no appreciable difference in the urea-nitrogen content of venous and capillary blood. Folin and Svedberg's ${ }^{3}$ micro-method was used for the estimation of the non-protein nitrogen. After the fasting specimen of blood had been withdrawn the child was given $15 \mathrm{grm}$. urea dissolved in $120 \mathrm{c.cm}$. of water. As the children were thirsty the drink was almost always taken readily. In none of the subjects did vomiting or any other untoward symptom follow the administration of the urea. Samples of blood were withdrawn 30, 60 and 120 minutes after the urea had been given. When specimens of urine could be obtained the urea was estimated with a view to gauging the renal efficiency.

In order to determine the normal levels of blood non-protein nitrogen at various intervals after taking urea, a series of 12 cases convalescent from various diseases and injuries was examined. In none of the cases was there reason to suspect that there was any disturbance in metabolism. None of them had been recently anæsthetized and none was receiving drug treatment. The ages ranged from 4 to 12 years. Summaries of the case reports are given in the appendix, 
The normal non-protein nitrogen curve.-The fasting non-protein nitrogen was found to lie between 18 and $40 \mathrm{mgrm}$. per cent. (Table 2). In all the cases a definite rise was observed within half an hour of the ingestion of the urea. The smallest increase noted was $4.6 \mathrm{mgrm}$. per cent. and the largest 35 mgrm. per cent., while the maximum value reached was $62.5 \mathrm{mgrm}$. per cent. One hour after the urea had been given 9 of the curves were continuing to rise. The most marked increase from the previous specimen was 14 mgrm., while the smallest was $2 \cdot 6$ mgrm., and the highest

TABLE 2.

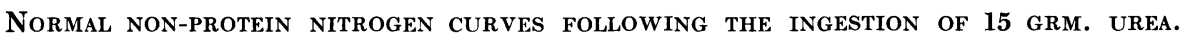

\begin{tabular}{|c|c|c|c|c|c|c|c|c|}
\hline \multirow{3}{*}{$\begin{array}{l}\text { No of } \\
\text { case }\end{array}$} & \multirow{3}{*}{$\begin{array}{l}\text { Age in } \\
\text { years }\end{array}$} & \multirow{3}{*}{ Disease } & \multicolumn{6}{|c|}{ Percentage of N.P.N. in blood : mgrm. per cent. } \\
\hline & & & Fasting & Hours & after & the inge & stion & of urea \\
\hline & & & level & $\frac{1}{2} \mathrm{hr}$ & & $1 \mathrm{hr}$. & & $2 \mathrm{hr}$. \\
\hline 1 & 4 & P̉ulm. fibrosis & $38 \cdot 1$ & $60 \cdot 9$ & & 74.5 & & $62 \cdot 5$ \\
\hline 2 & 10 & Neurosis & 26.7 & $59 \cdot 5$ & & 34.7 & & $31 \cdot 2$ \\
\hline 3 & 9 & $\begin{array}{l}\text { Spastic } \\
\text { diplegia }\end{array}$ & $13 \cdot 0$ & $32 \cdot 6$ & & $46 \cdot 8$ & & $39 \cdot 3$ \\
\hline 4 & 8 & $\begin{array}{l}\text { Conv. } \\
\text { ileo-colitis }\end{array}$ & $33 \cdot 0$ & $38 \cdot 0$ & & $45 \cdot 0$ & & $35 \cdot 0$ \\
\hline 5 & 8 & $\begin{array}{l}\text { Conv. } \\
\text { purpura }\end{array}$ & $31 \cdot 3$ & $42 \cdot 3$ & & $30 \cdot 5$ & & $30 \cdot 0$ \\
\hline 6 & 11 & Fracture & $38 \cdot 0$ & - & & $66 \cdot 0$ & & $30 \cdot 0$ \\
\hline 7 & 10 & $\begin{array}{l}\text { Conv. } \\
\text { appendicitis }\end{array}$ & 37.0 & $49 \cdot 0$ & & $57 \cdot 4$ & & $49 \cdot 0$ \\
\hline 8 & 6 & Fracture & $33 \cdot 1$ & $50 \cdot 0$ & & $52 \cdot 6$ & & $50 \cdot 0$ \\
\hline 9 & 10 & $\begin{array}{l}\text { Conv. } \\
\text { chest wound }\end{array}$ & $4 ! \cdot 0$ & $44 \cdot 6$ & & $54 \cdot 2$ & & $42 \cdot 3$ \\
\hline 10 & 4 & $\begin{array}{l}\text { Conv. } \\
\text { scalp wound }\end{array}$ & $37 \cdot 1$ & $46 \cdot 3$ & & $55 \cdot 5$ & & $16 \cdot 3$ \\
\hline 11 & 4 & $\begin{array}{l}\text { Mental } \\
\text { deficiency }\end{array}$ & $38 \cdot 0$ & $62 \cdot 5$ & & $47 \cdot 2$ & & $46 \cdot 3$ \\
\hline 12 & 4 & $\begin{array}{l}\text { Conv. } \\
\text { ilec-colitis }\end{array}$ & $19 \cdot 0$ & $44 \cdot 4$ & & $52 \cdot 6$ & $i$ & $47 \cdot 6$ \\
\hline
\end{tabular}

value actained was 74.5 mgrm. per cent. Three curves (Cases 2, 5 and 11) had by this time begun to return towards the fasting level. Two hours after the urea had been taken all the curves were on the downward trend, 3 had returned to within 2 or $3 \mathrm{mgrm}$. of the fasting level, 6 had fallen to within 20 mgrm. of the fasting level and 3 others were still more than $20 \mathrm{mgrm}$. above it. It is interesting to note that in both the oldest and the youngest of the group the apex of the curve had been reached within half an hour of the administration of the urea. This suggests that the size of the dose in relationship to the age of the child is of no moment. Taking these 12 cases into consideration it appears that the normal curve may be described as one 
which reaches its maximum point within 2 hours of the ingestion of 15 grm. urea (Fig. 1).

FIG. 1.

BLOOD NON-PROTEIN NITROGEN AFTER 15 GRM. UREA. Composite curve.

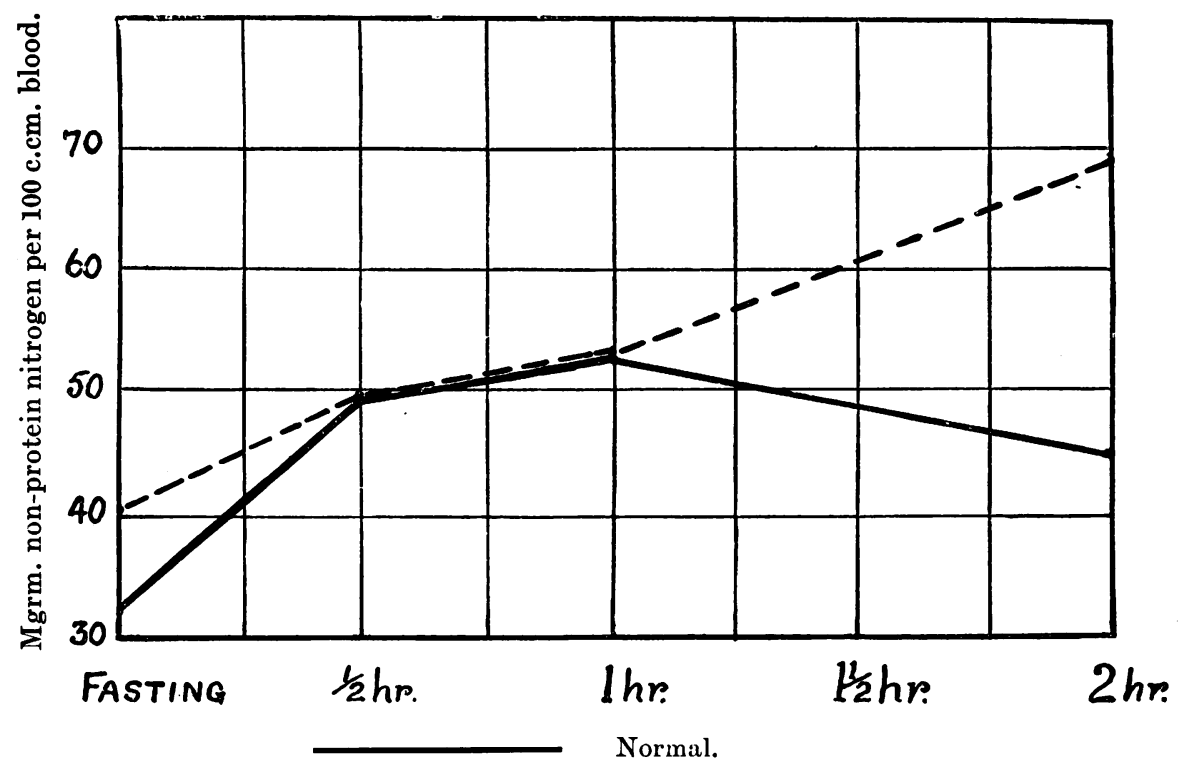

$-\infty-\infty$ Cases of hepatic disease.

The non-prutein nitrogen curve in liver disease.-Thirteen children in whom liver disease was known or suspected, were tested. The same procedure was followed as in the previous group. The ages of the children ranged from 1 to 10 years. The results are shown in Table 3, and summaries of the case reports are given in the Appendix. The fasting non-protein nitrogen lay between 26.7 and $52.6 \mathrm{mgrm}$. Thirty minutes after the urea had been taken all the curves, with the exception of one which remained stationary, were tending upwards. The rise at this stage was much less marked than that which occurred in the normal cases at the same stage, the average rise in this group being $8 \mathrm{mgrm}$. as compared with $16 \mathrm{mgrm}$. in the normal cases. One hour after the urea had been taken the values remained at practically the same levels as at 30 minutes. In one case only, a simple catarrhal jaundice, was there a rise of $15 \mathrm{mgrm}$. At 2 hours 6 had risen more than 20 mgrm. the greatest rise being in a case of catarrhal jaundice which increased from 39 to $79 \mathrm{mgrm}$. The curve in 5 cases had risen to a less degree, and in one case there was no change from the level found at one hour. Three hours after the urea had been given 3 curves were continuing to rise. By 4 hours all had begun to descend, and those which were estimated, at 5 hours showed a further fall towards the fasting level, 
The curves obtained following the administration of urea in hepatic disease differ in three main points from the curves found in normal individuals. These are (1) the higher average fasting non-protein nitrogen, (2) the slow rise, and (3) the height and prolongation of the curve. On account of the high fasting non-protein nitrogen it might be suggested that some disorder of the kidneys was responsible for the abnormal curves. In order to eliminate this possibility urea-concentration tests were carried out on 6 of the patients. The results which are shown in Table 3 were satisfactory in all the cases. The lowest fasting value was 1.82 grm. per cent. and the lowest level reached after the ingestion of the urea was $2 \mathrm{grm}$. per cent. while the majority were considerably higher. In Case 3 where the fasting non-protein nitrogen was $49 \mathrm{mgrm}$. per $100 \mathrm{c.cm}$., the urinary urea rose from $2 \cdot 18 \mathrm{grm}$. to $4.02 \mathrm{grm}$. after the urea had been given. From this example it would appear that inefficiency in excreting urea is not a cause of the high fasting non-protein nitrogen or of the abnormal curve.

The most plausible explanation of the increased fasting non-protein nitrogen appears to be that the liver is unable to retain the end-products of endogenous protein metabolism which thus accumulate in the blood. The delayed rise in the curve is possibly due to some defect in absorption from the bowel. The height and prolongation of the curves may be due to the diminished power of the diseased liver to retain or store the non-protein nitrogen.

\section{Summary.}

1. The non-protein nitrogen curve following 15 grm. urea in normal fasting children is described.

2. The non-protein nitrogen curve following $15 \mathrm{grm}$. urea in fasting children suffering from various forms of hepatic disease was found to be more prolonged than in normal subjects.

3. It is suggested that the non-protein nitrogen curve may prove a useful test of hepatic efficiency.

It is a pleasure to acknowledge my indebtedness to Professor G. B. Fleming and Dr. Noah Morris for their valuable advice and criticism. My thanks are also due to Dr. Stanley Graham and Mr. Matthew White for granting me facilities for examining cases in their wards.

\section{REFERENCES.}

1. Cohen, P., \& Levin, S. J., Arch. Int. Med., Chicago, 1927, XXXIX, 787.

2. Archer, H. E., \& Robb, G. D., Quart. J. Med., Oxford, 1924, XVIII, 274.

3. Folin, O., \& Svedberg, A., J. Biol. Chem., Baltimore, 1930, LXXXVIII, 85.

4. Johnstone, C., J. Clin. Invest., N.Y., 1931, IX, 209. 
Appendix.

\section{Summaries of case reports.}

Case 1.-Boy, $3 \frac{1}{2}$ years. Previous history, not important. Vomiting for 9 days, accompanied by dark urine and white stools. Jaundice of 4 days duration. Liver palpable $1 \frac{1}{2}$ in. below costal margin. Urine contained bile pigment.

Case 2.-Girl, 8 years. Previous history, not essential. Nausea and anorexia for 7 weeks. Intermittent jaundice for 4 weeks accompanied by light coloured stools, dark urine and occasional vomiting. Liver 4 in. below costal margin. Wassermann reaction negative. Microscopic blood examination, secondary anæmia. Fragility of red cells normal. Van den Bergh : 32 units, biphasic.

Case 3.-Girl, 5 years. Previous history, not essential. Loss of appetite and irritable 6 days ago. Next day vomiting began and was accompanied by jaundice, pale stools, dark urine and itchiness of the skin. Liver $2 \mathrm{in.}$ below costal margin. Wassermann reaction negative. Microscopic blood examination, secondary anæmia. Van den Bergh: biphasic reaction, 14 units.

Case 4.-Girl, 8 years. Previous history, unimportant. Nausea and anorexia for 4 days. Vomiting, constipation and abdominal pain for 3 days. Jaundice for 2 days.

Case 5.-Boy, 5 years. Previous history, acute rheumatism August, 1931. Heart not affected. Jaundice of 4 days duration accompanied by vomiting. Liver border 2 in. below costal margin.

Case 6. -Girl, 1 year and 4 months. Healthy baby, but always pale. Jaundice for 1 week. Liver palpable but not enlarged. Spleen 2 in. below costal margin. Microscopic blood examination, secondary anæmia. Trace of urobilin in urine. Van den Bergh : direct, negative; indirect, positive.

Case 7.-Girl, 8 years. Previous history, not important. Intermittent jaundice for 2 years. Constant for 6 months. During attacks stools are white and urine dark. Two months ago abdomen began to swell. Liver and spleen greatly enlarged. Urine; urobilin present, bilirubin absent. Fragility of red cells not increased. Van den Bergh : biphasic reaction, 11 units of bilirubin.

Case 8.-Girl, 10 years. Healthy until 7 years of age when in hospital with diphtheria, enlarged spleen found. Child otherwise well. Skin dark, pigmentation of flexures. No jaundice. Liver and spleen both enlarged. No glandular enlargement. Blood picture, secondary anæmia. Fragility of red cells not increased. Urine, no bile pigment. Van den Bergh : direct, negative; indirect, 2 units. Splenic puncture, Banti's disease.

Case 9.-Girl, 9 years. Adopted child, previous history unknown. On day of admission headache and vomited about 5 oz. bright red blood followed 2 hours later by vomiting of dark brown material. Physical examination negative. Benzidine test on stool, positive. Lævulose curve, positive.

Case 10.-Boy, 1 year. Diagnosis, biliary cirrhosis. Since birth has had 5 attacks of jaundice, accompanied by light stools and dark urine, which cleared within 1 week. Irritable and loss of appetite for 1 month. Swelling of abdomen noticed 2 weeks ago. Liver and spleen both greatly enlarged. Van den Bergh reaction: direct, negative; biphasic, positive; indirect, 3.5 units of bilirubin. Fragility of red cells, unaltered. Wassermann reaction, negative. Blood picture, secondary anæmia. 
Case 11.-Boy, 4 years. Healthy until last 5 weeks when he became listless and lost his appetite. Vomiting and right-sided abdominal pain for 4 days. Motions loose, urine dark. No jaundice. Abdomen tender and resistant. Fever present. At operation, gall bladder greatly distended and liver reached to umbilicus. No stones were found. Urine, no abnormal constituent. Lævulose tolerance test, positive.

Case 12.-Boy, 9 years. Swelling of abdomen dating from infancy. No symptoms. Liver 3 in. below costal margin. Lævulose curve, positive. Fifty per cent. rise in blood-sugar value following the ingestion of lævulose.

Case 13.-Girl, 4 years. Previous history, pyuria. General health good. Active child. Liver 2 in. below costal margin. Urine clear. Blood urea, 19·1 mgrm. per cent. 